\title{
A FAMÍLIA DE ONTEM, A FAMÍLIA DE HOJE: CONSIDERAÇÕES SOBRE O PAPEL DA MULHER NO DIREITO DE FAMÍLIA BRASILEIRO
}

\author{
Amanda Muniz Oliveira* \\ Rodolpho Alexandre Santos Melo Bastos**
}

SUMÁRIO: Introdução; 2 A mulher e as famílias: considerações preliminares; 3 A família ontem: Ordenações Filipinas, Consolidação das Leis Civis e Código de 1916; 4 A família boje: A Constituição de 1988 e o Código Civil de 2002; 5 Considerações Finais; Referências.

RESUMO: O presente ensaio procura resgatar o papel do Direito brasileiro na imposição e naturalização da ideia da mulher como indivíduo submisso. Tendo como ponto de partida alguns apontamentos sobre a pluralidade familiar e o advento do patriarcado ainda na pré-história, serão identificados dispositivos legais presentes no ordenamento nacional que contribuem para essa disparidade entre homens e mulheres, especificamente no direito de família. Para tanto, será realizada uma análise empírica documental a partir da análise de fontes primárias como as Ordenações Filipinas, a Consolidação das Leis Civis, o Código de 1916, a Constituição de 1988 e o Código de 2002, nos quais serão buscadas referências ao direito das mulheres no intuito de apresentar um panorama geral sobre os papéis de gênero definidos em âmbito familiar pelo Direito.

PALAVRAS-CHAVE: Direito de família; Gênero; Mulher.

\section{YESTERDAY'S AND TODAY'S FAMILY: THE ROLE OF WOMEN IN BRAZILIAN FAMILY LAW}

ABSTRACT: The role of Brazilian law in the imposition and naturalization of women as submitted individuals is analyzed. Within the point of view of familial plurality and the outcome of patriarchy in pre-history, the legal dispositions in Brazilian law which contribute towards disparities between males and females are identified, specifically in family legislation. A documentary empirical analysis is undertaken, foregrounded on the analysis of primary sources, such as the Philippine Ordinances, the Consolidation of Civil Laws, the 1916 Civil Code, the 1988 Constitution and the

Doutoranda em Direito pelo Programa de Pós-Graduação em Direito da Universidade Federal de Santa Catarina (PPGD/UFSC), Brasil; Bolsista CAPES. E-mail: amandai040@gmail.com

** Doutorando em História pelo Programa de Pós-Graduação em História da Universidade Federal de Santa Catarina (PPGH/UFSC), Brasil. 
2002 Code in which the rights of women are discussed to provide a general view on gender roles defined within the law of the family.

KEY WORDS: Family law; Gender; Women.

\section{LA FAMILIA DE AYER, LA FAMILIA DE HOY: CONSIDERACIONES SOBRE EL PAPEL DE LA MUJER EN EL DERECHO DE FAMILIA BRASILEÑO}

RESUMEN: El presente ensayo busca rescatar el papel del Derecho brasileño en la imposición y naturalización de la idea de la mujer como individuo sumiso. Teniendo como punto de partida algunos apuntamientos sobre la pluralidad familiar y la llegada del patriarcado aún en la prehistoria, serán identificados dispositivos legales presentes en el ordenamiento nacional que contribuyen para esa disparidad entre hombres y mujeres, en específico, en el derecho de familia. Para tanto, se realizará un análisis empírico documental a partir del análisis de fuentes primarias como las Ordenaciones Filipinas, la Consolidación de las Leyes Civiles, el Código de 1916, la Constitución de 1988 y el Código de 2002, en los cuales se buscarán referencias al derecho de las mujeres en el intuito de presentar un panorama general sobre los papeles de género definidos en ámbito familiar por el Derecho.

PALABRAS-CLAVE: Derecho de familia; Género; Mujer.

\section{INTRODUÇÃO}

A desigualdade no tratamento de homens e mulheres é uma questão antiga. Enquanto o filho varão era ensinado a comandar e a cortejar, as donzelas aprendiam a não levantar a voz contra pais e maridos e a manter sua virgindade intacta até a celebração do casamento. No ocidente, a família - assunto da moral, dos bons costumes e da religião judaico-cristã - deveria ser estritamente monogâmica, apesar de ser comum os maridos se deleitarem nos braços de cortesãs sem grandes preocupações. Já as esposas deviam se portar com respeito e decência, sendo o adultério feminino um pecado abominável e, em alguns sistemas jurídicos, um crime cuja pena poderia ser a morte pelas mãos do Estado ou pelas mãos do esposo.

Todavia, esta configuração patriarcal familiar não é natural. As configurações da família oriental, ou mesmo das famílias formadas em tribos aborígenes, diferem 
sobremaneira deste padrão ocidental eurocêntrico, o que nos fornece indícios não de uma organização familiar, mas de múltiplos tipos de famílias.

Neste sentido, pode-se observar que diversos elementos contribuíram para o enraizamento de um padrão familiar tido como absoluto e correto, como, por exemplo, os dogmas religiosos, que apresentam papéis bem definidos sobre o que é ser homem e marido, ou mulher e esposa. Assim, também os reis e os Estados auxiliaram na manutenção destes deveres masculinos e femininos, especialmente a partir do Direito: nas leis, podemos encontrar prescrições sobre direitos, deveres e crimes, inclusive no que se refere às organizações familiares, quase sempre desfavorecendo a mulher.

Desta forma, o presente ensaio procura identificar, no Direito brasileiro, normas que teriam contribuído para a diferença de tratamentos entre homens e mulheres, especialmente no que se refere ao Direito de família. Tais leis podem ser compreendidas tanto como um aparato coercitivo, quanto um discurso representativo, no sentido de que se inserem em determinados espaços temporais, refletindo práticas e ideologias inerentes de cada época e sociedade.

Inicialmente, serão feitas algumas considerações sobre as diferentes configurações familiares observáveis ao longo do globo, o que permitiu a alguns pesquisadores a vislumbrar a hipótese de que a mulher, outrora, havia assumido um papel central no seio da organização familiar (matriarcado); também serão apresentadas as razões pelas quais, segundo estes autores, o patriarcado se consolidou como sistema padrão e de como o Estado passa a intervir, por meio das leis, no núcleo familiar.

Em seguida, será necessário verificar os dispositivos relativos à família nas primeiras legislações brasileiras, a saber: Ordenações Filipinas, Consolidação das Leis Civis e Código Civil de 1916, no objetivo de perceber como se dava essa intervenção, especialmente no que se refere à condição feminina. Por fim, serão apresentados os dispositivos relacionados à família atualmente vigentes no Brasil, como a Constituição de 1988 e o Código Civil de 2002, apontando permanências e rupturas instauradas.

É importante destacar que o objetivo deste ensaio não é oferecer uma análise completa e detalhada de todos os documentos legais supracitados, mas de apresentar exemplos das práticas discursivas presentes no Direito em relação à condição da mulher dentro do núcleo familiar. 


\section{A MULHER E AS FAMÍLIAS: CONSIDERAÇÕES PRELIMINARES}

Mais do que uma unidade padronizada, o termo família indica um grupo variável cuja complexidade só pode ser compreendida a partir de uma série de fatores e olhares. Neste sentido, faz-se necessário rastrear, ainda que genericamente, seus contornos evanescentes, mutáveis conforme tempo, espaço e perspectiva do próprio pesquisador.

Para Friedrich Engels, até meados de 1860 a história da família resumiase "aos Cinco Livros de Moisés", ou seja, aos cinco primeiros livros do antigo testamento ${ }^{03}$. O autor aponta o jurista e antropólogo Johann Bachofen como precursor dos estudos sobre a origem das famílias, seguido pelo jurisconsulto John Mac Lennan e pelo antropólogo Lewis Morgan ${ }^{04}$. O trabalho deste último sobre as relações familiares por entre tribos indígenas na América irá embasar toda a tese de Engels em seu livro A Origem da Família, da Propriedade Privada e do Estado.

$\mathrm{Na}$ referida obra, Engels procura identificar as origens da família moderna, tendo como ponto de partida as pesquisas de Morgan ${ }^{05}$. Partindo de uma visão evolucionista da história, segundo a qual as tribos ameríndias estariam em um estágio civilizatório atrasado, o autor entende que as organizações familiares daquele tempo e espaço seriam similares às configurações no mundo dito civilizado, em épocas passadas. Desta forma, aplica as observações de Morgan à sociedade grega, romana e germânica, acreditando, assim, ter encontrado a origem da família. Apesar do notório equívoco, suas observações serão úteis para exemplificar a característica multifacetada daquilo que convencionou-se chamar família - quando um termo mais adequado, diante das múltiplas configurações possíveis, seria famílias.

Engels discorre sobre agrupamentos familiares centrais, que seriam identificáveis em todas as partes do globo, com nuances diferenciadas, mas núcleos similares $^{06}$. O primeiro destes agrupamentos seria a família consangüinea, que caracterizava-se pela poligamia mútua entre irmãos e primos; a relação entre pais e filhos já não seria verificável, como nos tempos mais remotos, quando seria impossível falar em família ${ }^{07}$.

\footnotetext{
${ }^{03}$ ENGELS, Friedrich. A origem da família, da propriedade privada e do Estado: trabalho relacionado com as investigações de L. H. Morgan. Rio de Janeiro: Civilização Brasileira, 1979, p. 6.

${ }^{04}$ Ibidem, 1979. p. 07-16.

${ }^{05}$ Ibidem, 1979. p. 03-04.

${ }^{06}$ Ibidem, 1979. p. 37-66.

${ }^{07}$ Ibidem, 1979. p. 38-39.
} 
O segundo seria a família punaluana, que excluirá as relações entre irmãos, mantendo, porém, a característica poligâmica. Os maridos que possuíam esposas em comum, bem como as mulheres que possuíam maridos em comum, chamavam-se uns aos outros de punalua, companheiro íntimo, o que explica a nomenclatura deste grupo $^{08}$. O Aautor concorda com Morgan no que se refere à motivação da mudança do núcleo consanguíneo ao punaluano: a seleção natural, no sentido de que grupos que proibiram as uniões entre irmãos teriam tido um progresso mais veloz do que aqueles que permitiam tais uniões.

O terceiro agrupamento seria a família sindiásmica, caracterizada pela proibição total de uniões entre parentes e pelo início das relações monogâmicas:

Neste estágio, um homem vive com uma mulher mas de maneira tal que a poligamia e a infidelidade ocasional continuam a ser um direito dos homens, embora a poligamia seja raramente observada por razões econômicas; ao mesmo tempo, exige-se a mais rigorosa fidelidade das mulheres, enquanto dure a vida em comum, sendo o adultério destas cruelmente castigados. O vínculo conjugal, todavia, dissolve-se com facilidade por uma ou por outra parte, e depois, como antes, os filhos pertencem exclusivamente à mãe $e^{09}$.

Torna-se interessante destacar aqui algumas particularidades deste agrupamento específico. Para Engels, a família sindiásmica manteria o que ele denomina lar comunista, em detrimento do lar particular:

lar comunista significa predomínio da mulher na casa; tal como o reconhecimento exclusivo de uma mãe própria, na impossibilidade de conhecer com certeza o verdadeiro pai; significa alto apreço pelas mulheres, isto é, pelas mães. Uma das idéias mais absurdas que nos transmitiu a filosofia do século XVIII é a de que na origem da sociedade a mulher foi escrava do homem. Entre todos os selvagens e em todas as tribos que se encontram nas fases inferior, média e até (em parte) superior da barbárie, a mulher não só é livre como, também, muito considerada $^{10}$.

Neste sentido, tendo em mente o papel de destaque que a mulher gozava nos agrupamentos familiares poligâmicos, especialmente porque a linha sucessória

\footnotetext{
${ }^{08}$ ENGELS, op. cit., 1979. p. 40.

09 Ibidem, 1979. p. 49.

${ }^{10}$ Ibidem, 1979. p. 50.
} 
só era identificável a partir da mãe, o autor defende que a constituição de uma família monogâmica aos moldes da sindiásmica, que teria originado a família moderna, só teria sido possível por um desejo feminino:

Quanto mais as antigas relações sexuais perdiam seu caráter inocente primitivo e selvático, por forçado desenvolvimento das condições econômicas e, paralelamente, por força da decomposiçã̃o do antigo comunismo, e da densidade cada vez maior da população, tanto mais envilecedoras e opressivas devem ter parecido essas relações para as mulheres, que com maior força deviam ansiar pelo direito à castidade, como libertação, pelo direito ao matrimônio, temporário ou definitivo, com um só homem. Esse progresso não podia ser devido ao homem, pela simples razão, que dispensa outras, de que jamais, ainda em nossa época, lhe passou pela cabeça a idéia de renunciar aos prazeres de um verdadeiro matrimônio por grupos. Só depois de efetuada pela mulher a passagem ao casamento sindiásmico, é que foi possível aos homens introduzirem a estrita monogamia - na verdade, somente para as mulheres ${ }^{11}$.

Engels passa, então, a destrinchar essa transição, enfatizando a perda do protagonismo feminino na entidade familiar ${ }^{12}$. Uma das principais razões refere-se justamente à questão sucessória: tendo o homem apenas uma mulher e sendo capaz de acumular riquezas, seus bens não eram transmitidos aos filhos, mas à esposa e seus parentes, em virtude do ainda vigente direito materno. Esta regra foi, então, abolida, embora não se saiba bem nem quando e nem como, visto que se trata de uma transição pré-histórica. Todavia, para Engels trata-se de uma revolução crucial, pois irá originar o patriarcado.

O desmoronamento do direito materno, a grande derrota histórica do sexo feminino em todo o mundo. $\mathrm{O}$ homem apoderou-se também da direção da casa; a mulher viu-se degradada, convertida em servidora, em escrava da luxúria do homem, em simples instrumento de reprodução. Essa baixa condição da mulher, manifestada sobretudo entre os gregos dos tempos heróicos e, ainda mais, entre os dos tempos clássicos, tem sido gradualmente retocada, dissimulada e, em certos lugares, até revestida de formas de maior suavidade, mas de maneira alguma suprimida. [...] Esta forma de família assinala a passa-

${ }_{11}$ ENGELS, op. cit., 1979. p. 56.

${ }^{12}$ Ibidem, 1979. p. 58-66. 
gem do matrimônio sindiásmico à monogamia. Para assegurar a fidelidade da mulher e, por conseguinte, a paternidade dos filhos, aquela é entregue, sem reservas, ao poder do homem: quando este a mata, não faz mais do que exercer o seu direito ${ }^{13}$.

É assim então que teria se constituído a família monogâmica, caracterizada sobretudo por uma centralização do poder nas mãos do homem, patriarca ${ }^{14}$. Caracterizada pela exigência de fidelidade feminina e pela dificuldade de sua dissolução (já que apenas o homem pode romper tais laços), a família monogâmica será perpetuada até a modernidade com o auxílio das instituições religiosas e das instituições jurídicas.

Conforme advertido anteriormente, os escritos de Engels não podem ser considerados verdades absolutas por partilharem de uma perspectiva evolucionista e universalista. Todavia, de seu trabalho podemos obter duas interessantes conclusões: a organização familiar monogâmica não é o único e nem o mais antigo modelo possível de família; a mulher nem sempre foi submissa ao homem no que se refere às organizações familiares diversas, como por exemplo nas tribos indígenas.

Neste mesmo sentido, Rosie Marie Muraro ao escrever a introdução para uma das edições brasileiras do Martelo das Feiticeiras, manual não oficial dos inquisidores escrito no século $\mathrm{XV}$, resgata alguns elementos sobre a constituição da família patriarcal. Conforme a autora, na pré-história da humanidade a mulher era reverenciada por ser capaz de gerar vidas, de forma que o homem ignorava seu papel na procriação humana ${ }^{15}$. Além disso, como a coleta de alimentos (função feminina) e a caça aos animais (função masculina) eram essenciais para a vida das tribos, homem e mulher coexistiam em igualdade. Porém:

É no decorrer do neolítico que em algum momento o homem começa a dominar sua função biológica reprodutora e, podendo controlá-la, pode também controlar a sexualidade feminina. Aparece então o casamento como o conhecemos hoje, em que a mulher é propriedade do homem e a herança se transmite através da descendência masculina. [...]. Nesse contexto, quanto mais filhos, mais soldados e mais mão-de-obra barata para arar a terra. As mulheres tinham sua sexualidade

${ }^{13}$ ENGELS, op. cit., 1979. p. 61-62.

${ }^{14}$ Ibidem, 1979. p. 62.

${ }^{15}$ MURARO, Rose Marie. Breve Introdução Histórica. In: KRAMER, Heinrich; SPRENGER, James. O martelo das feiticeiras. Rio de Janeiro: Rosa dos Tempos, 1997. p. 06. 
rigidamente controlada pelos homens. O casamento era monogâmico e a mulher obrigada a sair virgem das mãos do pai para as mãos do marido. Qualquer ruptura dessa norma poderia significar a morte. Assim também o adultério: um filho de outro homem viria a ameaçar a transmissão da herança que se fazia através da descendência da mulher. A mulher fica, então, reduzida ao âmbito doméstico. Perde qualquer capacidade de decisão do domínio público, que fica inteiramente reservado ao homem ${ }^{16}$.

Para Muraro essa situação irá perdurar até a Idade Média, quando a religião cristã se propaga ${ }^{17}$. Apesar de uma relação confusa e conturbada entre feminino e masculino, é neste período que os homens abandonam seus espaços para lutarem nas cruzadas, de forma que esta ausência lança as mulheres ao domínio público, mas apenas provisoriamente, enquanto o masculino não retorna:

Na Alta Idade Média, a condição das mulheres floresce. Elas têm acesso às artes, às ciências, à literatura. Uma monja, por exemplo, Hrosvitha de Gandersheim, foi o único poeta da Europa durante cinco séculos. Isso acontece durante as cruzadas, período em que não só a Igreja alcança seu maior poder temporal como, também, o mundo se prepara para as grandes transformações que viriam séculos mais tarde, com a Renascença. E é logo depois dessa época, no período que vai do fim do século XIV até meados do século XVIII que acontece o fenômeno generalizado em toda a Europa: a repressão sistemática do feminino. Estamos nos referindo aos quatro séculos de "caça às bruxas"18.

Apesar deste florescimento feminino medieval ser bastante questionável, principalmente porque o acesso a esses conhecimentos era limitado a um pequeno número de mulheres nobres não sendo regra mas exceção, o período entre os séculos XIV e XVIII será crucial para a definição e enraizamento do papel da mulher e também da família. A Revolução Francesa, evento que marca o advento da modernidade, é um dos importantes acontecimentos que irá reafirmar e transportar para os dias atuais os papéis de mãe, esposa e senhora do lar.

Conforme Anália Torres, apesar da Revolução Francesa romper com a ideia de privilégios herdados com o nascimento, concebendo a ideia de direitos inerentes ao homem e permitindo assim uma maior mobilidade social, tais modificações não

\footnotetext{
${ }^{16}$ MURARO, op. cit., 1997. p. 07.

17 Ibidem, 1997. p. 13.

18 Ibidem, 1997. p. 13.
} 
englobavam o feminino ${ }^{19}$. Segundo o sociólogo Ulrich Beck, no que se refere às relações familiares entre homem e mulher na época, a lógica feudal permanecia, pois determinados espaços eram destinados às mulheres pelos critérios de nascimento e gênero ${ }^{20}$.

Neste sentido, são numerosos os autores que se dedicaram aos estudos da família. Tem-se por exemplo Durkheim, que apesar das críticas ${ }^{21}$, identificará o que denomina família conjugal moderna, formada preponderantemente pelo casal e pelos filhos e marcada por direitos e obrigações dos genitores para com a prole. Neste sentido, Durkheim é um dos primeiros a identificar a intervenção estatal no âmbito da família:

$O$ autor [Durkheim] ilustra a sua ideia quando refere a necessidade de intervenção estatal a propósito, por exemplo, da protecção dos órfãos, ou da limitação à intervenção dos pais quando eles excedem certos limites (Durkheim, 1892, 1975: 38). E defende que os laços de parentesco são indissolúveis, porque doravante há normas - direitos e deveres - que regem o contrato específico que é o casamento e a filiação, não podendo ninguém que se tenha submetido a essas normas subtrairse a elas. Enquanto na família patriarcal o poder do pai não tem limites porque, teoricamente, será sempre em nome do colectivo e do interesse "privado" do grupo familiar que ele agirá, na família conjugal moderna, liberta das amarras do parentesco e de interesses particulares do grupo familiar que se imponham à vontade das pessoas, deve estar a cargo do Estado a regulação dos interesses, a protecção dos mais frágeis. Neste sentido é esclarecedora a expressão que Durkheim utiliza: "É o Estado que, na pessoa do magistrado, preside ao conselho de família"'22.

19 TORRES, Anália Maria Cardoso. Relatório da Unidade Curricular: Sociologia da Família Teorias e Debates. Lisboa, 2010. Disponível em: < http://migre.me/uxx7r > . Acesso em: 01 ago. 2016. p. 38.

${ }^{20}$ BECK, Ulrich. Risk Society: Towards a New Modernity. London: Sage Publications, 1992. p. 107.

${ }^{21}$ As críticas feitas a Durkheim são resumidas por Anália Torres: "A ideia da passagem da família paternal à chamada família conjugal moderna é tão conhecida e divulgada quanto criticada. Demógrafos e historiadores da família puseram em causa a perspectiva de Durkheim, ao demonstrarem que estas passagens poderiam configurar-se de forma mais complexa e que, sobretudo, não se deveria falar, linearmente, do retraimento da família, na medida em que noutras formas anteriores de organização social a família também assumira tamanho reduzido e formas de relacionamento semelhantes. Mas ninguém pode contestar que foi exactamente no sentido indicado por Durkheim que evoluíram as relações familiares e as normas a elas associadas. [...] Se é verdade que havia excessiva simplificação e homogeneização nesta perspectiva, Durkheim, apesar de tudo, acertou no essencial quanto ao sentido das transformações verificadas" (TORRES, Anália Maria Cardoso, op. cit. 2010. p. 40).

${ }^{22}$ TORRES, op. cit., 2010. p. 44. 
Observa-se, portanto, que a organização social compreendida como família passa em determinado momento, passa a ser regida pelo direito estatal. Assim, prosseguir nas análises históricas e sociológicas sobre a família a partir deste ponto extrapola em muito os objetivos deste ensaio. Identificar-se-á, portanto, de que forma essa atuação estatal ocorreu, e ainda ocorre, especialmente no que se refere às mulheres. Serão buscados exemplos e indícios no direito estatal brasileiro, levando em consideração as Ordenações Filipinas, a Consolidação das Leis Civis, o Código Civil de 1916 e o Código Civil de 2002. De maneira alguma pretende-se analisar de forma exauriente cada um destes documentos legais; serão apontados alguns elementos que evidenciem o tratamento jurídico relativo à família, especialmente no que se refere à figura feminina.

\section{A FAMÍLIA ONTEM: ORDENAÇÕES FILIPINAS, CONSOLIDAÇÃO DAS LEIS CIVIS E CÓDIGO DE 1916}

A família hoje é regulamentada pelo Direito brasileiro principalmente pelo Direito Civil, que trata, em geral, das relações entre indivíduos: contratos, vendas, sucessões, dentre outros. Todavia, as primeiras leis a disporem sobre a família no Brasil são as Ordenações Filipinas, que atracaram em solo nacional junto aos portugueses no período colonial. De acordo com Flávia Vieira e Edvania Silva:

O Estado Português, desde muito cedo, já demonstrava preocupação na codificação de suas leis. Por isso, desde o século $\mathrm{XV}$, as leis do reino passaram a ser reunidas em um diploma normativo, dando origem ao que denominavam de Ordenações. Tais códigos levavam o nome do monarca que exercia o poder à época de sua publicação $0^{23}$.

Conforme Ruy Rosado, tais ordenações irão vigorar até 1916, pois:

Logo após a Independência, a Lei de 20 de outubro de 1823 determinou vigorassem no Império do Brasil as Ordenações Filipinas, as Leis e Decretos de Portugal promulgados até 25 de abril de 1821, enquanto se não publicasse um novo Código. A Constituição de 1824 reconheceu a necessidade de se organi-

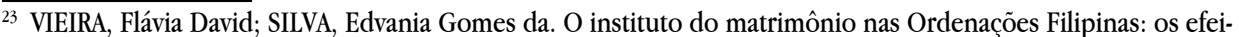
tos de sentido de "casamento" na legislação portuguesa aplicada no Brasil. In: Linguasagem, São Carlos, v. 23, n. 1, 2015. Disponivel em: < http://migre.me/uxxph> Acesso em: 01 ago. 2016. p. $05-06$.
} 
zar, o quanto antes, um Código Civil e um Criminal, fundado nas sólidas bases da Justiça e da Eqüidade. Em 1830 e 1850 foram promulgados os Códigos Criminal e Comercial, respectivamente. Para a legislação civil, entretanto, adotou-se o critério de aperfeiçoá-la em duas fases: na primeira, seria feito o levantamento e a consolidação de toda a legislação vigente até ali ("formar um novo corpo, mas de direito já vigente"); na segunda, com o auxílio do que fora feito, tratar-se-ia de elaborar o texto do novo Código Civil ("formar um corpo novo de direito novo") $)^{24}$.

Desta forma, em 1858 a Consolidação das Leis Civis, ou seja, a reorganização das Ordenações Filipinas realizada pelo jurista Teixeira de Freitas, será aprovada pelo Imperador, de forma que novas leis civis apenas entrarão em vigor em 1916, com o Código Civil de Clóvis Bevilaqua, que por sua vez será revogado pelo Código Civil de 2002. Neste primeiro momento, serão analisadas as legislações mais antigas, deixando o Código mais recente para o próximo tópico.

No que se refere às Ordenações Filipinas, estas eram divididas em 5 volumes, a saber: I) Direito Administrativo e Organização Judiciária; (II) Direito dos Eclesiásticos, do Rei, dos Fidalgos e dos Estrangeiros; (III) Processo Civil; (IV) Direito Civil e Direito Comercial; (V) Direito Penal e Processo Penal.

Em relação ao casamento, este e seus atos próprios eram de responsabilidade das legislações eclesiásticas, até 1890, pois apenas com a Constituição de 1891 haverá a separação entre Estado e Igreja, de forma que o instituto passa a ser assunto estatal $^{25}$.

Porém, nos vários livros das Ordenações Filipinas é possível encontrar diversos dispositivos em relação aos direitos e deveres esperados das esposas e maridos. No Livro II, Título 37, por exemplo, dispõe-se que mulher com renda superior a cinquenta mil reis precisava pedir autorização do rei para se casar, sob pena de perder seus bens.

Mais significativos para o presente ensaio, entretanto, são os Livros IV e V. O primeiro dispõe de uma série de regras relativas aos bens do casal, como por exemplo, o Título 46 que estabelece o regime universal de bens como padrão ${ }^{26}$,

\footnotetext{
${ }^{24}$ ROSADO, Ruy. Indicação Literária: consolidação das leis civis. In: FREITAS, Augusto Teixeira de. Consolidação das Leis Civis. Brasília: Senado Federal, 2003. p. 04.

${ }^{25}$ AMARAL, Isabela Guimarães Ribeiro do. Inferiorizando mulheres no período imperial brasileiro: a influência do direito. In: Anais do XXVI Simpósio Nacional de História - ANPUH. São Paulo, julho 2011. Disponível em: $<$ http://migre.me/uxxUf>. Acesso em: 01 ago. 2016. p. 08.

${ }^{26}$ Este regime poderia ser alterado conforme a vontade dos cônjuges.
} 
válido apenas para indivíduos casados, e o Título 61 elenca uma curiosa regra que se refere ao Direito Velleano: uma norma que desobriga as mulheres a atuarem como fiadoras, em razão de fraqueza do entender.

Observa-se aqui a proteção jurídica à família constituída sobre as regras do casamento religioso, pois a divisão universal de bens só seria presumida quando os indivíduos fossem casados. Uniões informais, os chamados concubinatos, encontravam-se desprotegidas desta proteção jurídica, o que sugere uma clara tentativa de instituir o casamento religioso como regra, em contraposição às uniões informais. Neste mesmo sentido, levando em consideração que o homem seria o grande proprietário, dono e herdeiro de patrimônios, as mulheres concubinas tendiam a ser mais atingidas por esta norma, pois não seriam sucessoras legítimas de seus concubinos.

No que se refere à questão da fiança, infere-se uma tentativa jurídica de proteger a mulher, já que, conforme o pensamento representado na norma, ela teria menor capacidade de entendimento, podendo ser facilmente ludibriada para contrair dívidas de terceiros.

Sobre a sucessão, o Livro IV, Título 95, dispõe que falecido o marido, a mulher ficaria "em posse do cabeça de casal", sendo sua herdeira meeira para que se realize a partilha. Interessante destacar que cabeça de casal é a pessoa responsável pela administração da herança e a quem os herdeiros vêm pedir partilha, de forma que a lei estabelece este papel à mulher como um remédio. A nota de rodapé $\mathrm{n}^{\mathrm{o}}$ 2 , encontrada na $14^{\mathrm{a}}$ edição das Ordenações Filipinas, parece corroborar essa interpretação:

Sobre não ser a da mulher uma posse verdadeira, nem em vida nem por morte do marido, não adoptamos a doutrina da sua nota na parte $[. .$.$] em que das palavras - o marido por morte$ da mulher continua a posse velha, diferentes das que emprega com referência a mulher - fica em posse e cabeça de casal - infere que ela não tem posse enquanto vive 0 marido ${ }^{27}$.

Há nesta norma, portanto, uma explícita indicação de que a cabeça do casal só passa a mulher em ocasião de sua morte, ou seja, trata-se de momento excepcional; na ausência do homem, não há a quem recorrer e por isso chama-se a mulher.

${ }^{27}$ Ordenações Filipinas, livro IV. 14. ed. Rio de Janeiro: Typ. do Instituto Philomathico, 1870. Disponível em: $<$ http://migre.me/uxzTS > . Acesso em: 01 ago. 2016. p. 949. 
Em relação às viúvas, no Livro IV, Título 108, há um dispositivo que as impede de usufruir livremente de sua posse, caso seja provado em juízo que gasta seus bens de forma indevida. Nestes casos, os bens da viúva são entregues a um administrador que irá gerir as finanças e controlar seus investimentos. Conforme Amaral: "Vê-se que, pelas Ordenações, a justificativa para tal atitude era 'a fraqueza do entender das mulheres'. Havia quase o estabelecimento de uma consequência lógica de que mulheres viúvas seriam pródigas. Em relação ao homem, contudo, não havia previsão semelhante" ${ }^{\text {. }}$. Assim a lei já presume que a mulher viúva é mais suscetível de gastar desordenadamente sua herança, pois a mulher possuiria uma certa fraqueza do entender - justificativa utilizada também para retirar da mulher a condição de fiadora, conforme explicado anteriormente.

De maneira geral, o discurso patrimonialista presente nas Ordenações Filipinas pode ser resumido da seguinte maneira:

as referências encontradas sobre o casamento são em sua maior parte destinadas à proteção deste contrato, sendo esta a natureza preponderante atribuída ao casamento no período estudado. E que no código sob análise as questões vinculadas ao matrimônio giravam em torno, principalmente, da regulamentação dos bens e das obrigações entre os cônjuges, como a doação de bens feita pelo marido sem outorga da mulher e da proteção dos bens do casal, sobretudo nos casos envolvendo adultério ${ }^{29}$.

Já no Livro $\mathrm{V}$, que trata das questões criminais, encontram-se punições severas no que se refere à sacralidade da família. Conforme a historiadora Helen Pimentel, o adultério é tratado em detalhes na legislação, sendo destrinchado em diversas modalidades ${ }^{30}$. O Título 25 , por exemplo, estabelece pena de morte para o homem que se envolver com mulher casada, e também para a esposa adúltera; a pena é modificada, porém, caso o amante possua melhor condição financeira que o marido traído.

Quando o homem é o adúltero, entretanto, a situação se modifica drasticamente, pois o Título 28 estabelece penas pecuniárias e exílio: "Enquanto a desonra de um marido é punida com a morte do amante e da esposa, o adultério de

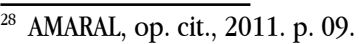

${ }^{29}$ VIEIRA; SILVA, op. cit., 2015. p. 07-08.

${ }^{30}$ PIMENTEL, Helen Ulhôa. Casamento e sexualidade: a construção das diferenças. Florianópolis: Mulheres, 2012. p. 76.
} 
um homem casado nem recebe essa denominação"31. De fato, o crime é listado no Livro V como Dos Barregueiros Casados e de suas Barregãs.

O crime de bigamia, contrair matrimônio mais de uma vez, é encontrado do Livro V, Título 19; sua punição é a morte, tanto para homens quanto para mulheres. As penas não seriam aplicadas nas seguintes situações: "se o condenado for menor de 25 anos; se o condenado for fidalgo e casar com mulher de baixa condição e se a primeira mulher for fugida e não se souber se está viva ou não"32.

Observe-se que caso o bígamo se case com mulher de condição financeira inferior à sua em razão de desaparecimento de sua esposa, não enfrentará a pena. $\mathrm{O}$ mesmo não vale para senhoras fidalgas que se casem em razão do desaparecimento do esposo, demonstrando um tratamento diferenciado para homens e mulheres na mesmíssima situação.

Outro dos crimes elencados no Livro V, Título 22, é o de casamento sem o consentimento dos tutores (pai, mãe, avô, senhor) da noiva virgem ou viúva com idade de até 25 anos. A pena é o exílio e a perda da fazenda; tal pena não será aplicada, porém, caso o noivo seja pessoa conhecida e o casamento seja mais vantajoso para a noiva que qualquer outro estipulado pelos tutores. É interessante destacar que o consentimento da noiva pouco importa; o que vale é ora a permissão dos seus responsáveis, ora o lucro financeiro.

Com a Proclamação da Independência, a situação jurídica da mulher no direito de família pouco se modifica. Em 1822 foi promulgada

a lei de 20 de outubro de 1823 que determinou que continuassem em vigor as Ordenações, leis, regimentos, alvarás, decretos e resoluções promulgadas pelos reis de Portugal até 25 de abril de 1821, "enquanto se não organizar um novo código ou não forem especialmente alteradas". Já a Constituição do Império, promulgada em 1824, determinou em seu art. 179, n. XVIII a "necessidade de se organizar, quanto antes, um código civil e um criminal, fundado em sólidas bases de Justiça e Equidade". O fato é que esse dispositivo da Constituição foi cumprido apenas parcialmente: o código criminal é promulgado em 1830 e o código comercial, em 1850. Já o código civil deveria esperar o ano de 1916, já em pleno século XX e em plena República (o regime imperial brasileiro teve fim em 1889), de modo que a intenção daquela lei de 1823 (o que equivale a dizer: a vigência provisória das ordenações e da le- 
gislação portuguesa) acabou por se realizar somente 1916, ao menos se tomada a legislação civil de um modo global ${ }^{33}$.

Desta forma, em razão das diversas leis esparsas, da aplicação de jurisprudências e costumes, o imperador solicitou ao jurista Teixeira de Freitas que realizasse a Consolidação das Leis Civis, que entrou em vigor no ano de 1858. A Consolidação de Teixeira de Freitas possui uma parte geral, referente às pessoas e às coisas, e duas partes especiais: uma referente aos direitos pessoais, direito de família e obrigações, e outra sobre direito reais e sucessões. Saliente-se que a Consolidação não se trata de uma inovação propriamente dita, mas de um agrupamento do direito vigente à época, de maneira mais sistemática. Na Consolidação, é possível encontrar diversos exemplos da condição feminina no Direito e de seu tratamento diferenciado em relação aos homens.

Inicialmente, no que se refere à capacidade para os atos da vida civil ${ }^{34}$, a Consolidação estabelece em seu artigo $8^{\circ}$ que a maioridade se dá aos vinte e um anos, excetuando-se os chamados filhos famílias (aqueles que ainda dependem financeiramente dos pais) - sem distinção de sexo. Todavia, existia uma diferença sutil, perceptível quando do casamento: enquanto o homem, ao se casar, libertavase da esfera de poder paterna e passava a ser o cabeça do casal, a mulher tornava-se juridicamente submissa ao marido, pois era ele quem detinha o poder decisório na esfera familiar ${ }^{35}$. Há ainda uma informação relevante: as viúvas e as solteiras maiores não possuíam sua capacidade civil limitada; apenas as mulheres casadas ${ }^{36}$. Trata-se não de uma imposição legal, mas de uma construção doutrinária, chamada de poder marital, por sua vez embasada nos costumes. O jurista Loureiro afirma:

Como porém a boa ordem exige imperiosamente que haja um chefe nesta sociedade, e não pode ser senão um dos dois; e como, por outra parte, a mesma natureza indica ser o homem, por ser o mais inteligente, o mais experimentado, o mais ágil em todos os negócios da vida, e ao mesmo tempo o mais forte; com razão e justiça devem competir a este alguns direitos especiais, os quais constituem o poder marital ${ }^{37}$.

\footnotetext{
${ }_{33}$ FONSECA, Ricardo Marcelo. A cultura jurídica brasileira e a questão da codificação civil no século XIX. In: Revista da Faculdade de Direito da UFPR, v. 44, n. 0, 2006. Disponível em: < http://migre.me/uxzqO> Acesso em: 01 ago. 2016. p. 65.

${ }^{34}$ Assinar documentos, realizar compras e vendas e fechar negócios, por exemplo.

35 AMARAL, op. cit., 2011. p. 03.

${ }^{36}$ Ibidem, 2011. p. 03.

${ }^{37}$ Ibidem, 2011. p. 04.
} 
O próprio Teixeira de Freitas, autor da Consolidação, seria contrário ao instituto, como ele mesmo escreve: "Nada mais repugnante à verdade, que - essa imaginada deslocação de direitos, de que formou-se o poder marital, e resulta a incapacidade da mulher; - esse acusado roubo de faculdades, - a suposta incapacidade por criação da lei sem defeito natural da mulher!!! 38 "

Outro ponto que merece destaque no âmbito da Consolidação, refere-se à permissão para o casamento. De acordo com os artigos 101, 102 e 103, os filhos menores e os filhos família que se casassem sem a permissão de seus responsáveis, estariam sujeitos a pena de deserdação e perda do direito de pedir alimentos. Essas penas aplicavam-se aos homens, independentemente da idade, e às mulheres que se casassem sem autorização até os 21 anos. Caso a mulher ainda dependesse de sustento dos responsáveis, mas se casasse após os 21 anos sem autorização deles, não seria punida. Este dispositivo resguarda, na verdade, um pensamento conservador:

Se a aplicação de pena para as mulheres se limitava à idade máxima de vinte e um anos é porque, nessa idade, a filha já deveria ter cumprido o seu papel social: o de se casar. Por maior que fosse a contrariedade do pai, em alguns casos, seria mais benéfico resignar-se com o casamento realizado a contragosto do que correr o risco de ter uma filha solteira em idade não muito atrativa para o matrimônio ${ }^{39}$.

Um outro exemplo do tratamento desigual que legitimava e normalizava a diferenciação entre homens e mulheres a partir do instrumento jurídico, referese à questão da deserdação dos filhos. A Consolidação, em seu artigo 1.016, §8 elenca a perda da virgindade como um motivo legítimo de exclusão da filha da linha sucessória; sobre os filhos, nada é mencionado. Assim:

Pode-se notar a importância social que era dada ao matrimônio e à virgindade da mulher. Os matrimônios das mulheres eram, em grande parte, arranjados por seus pais, devido a interesses políticos, econômicos e sociais. Logo, era uma afronta muita grande desobedecer ao destino traçado pelo pai e se casar com pessoa que ele não aprovava. Já a virgindade dizia respeito à honra da mulher e à boa imagem de sua própria família. Em relação a esse assunto, Trigo de Loureiro, em sua obra, acrescenta, em nota, que "a severidade desta pena já não se compadece com a doçura dos costumes do nosso tempo"

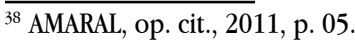

${ }^{39}$ Ibidem, 2011. p. 06. 
(LOUREIRO, 2004, p. 319). Ou seja, o jurista destaca o desuso e injustiça dessa norma ${ }^{40}$.

Com estes exemplos, é possível vislumbrar o tratamento do Direito no que se refere aos papéis femininos, especialmente no âmbito da família. Mesmo que as Constituições de 1824 (artigo 179, XII) e de 1891 (artigo 72, §2) estabeleçam a igualdade jurídica de todos perante a lei, a virgindade, a fidelidade, a subserviência ao pai e ao marido, e a naturalização de uma suposta fraqueza de entender, são elementos que irão normatizar a conduta feminina desta época.

Melhor sorte não encontrarão as mulheres brasileiras quando da sanção do Código Civil de 1916, escrito pelo jurista Clóvis Beviláqua:

o primeiro Código Civil brasileiro aprovado em 1916 instituiu o modelo oficial de família e, dentro dela, os modelos também de marido e de esposa com obrigações mútuas, mas em espaços distintos e hierarquicamente separados, conforme observou Elizandra Klem Coutinho. Esse aparato legislativo foi fortemente inspirado pela filosofia positivista de Augusto Comte que sustentava as idéias sobre o progresso da humanidade pela aplicação de princípios racionais e científicos. [...] As mulheres, nesta corrente de pensamento, eram consideradas guardiãs da moral da família, responsáveis pela manutenção da ordem da casa, pela educação da prole, além de servirem de musas inspiradoras para o marido e os filhos. Regina Caleiro argumenta que os positivistas republicanos pleiteavam "a complementaridade biológica, mental e social entre homens e mulheres, mas apesar de companheiras, as mulheres não eram iguais aos homens". Neste sentido, o código civil de 1916 só foi aprovado depois de terem sido retiradas as "disposições liberais" como aquelas que ampliavam os direitos das mulheres dentro da família e o divórcio. Ele não só legislou o status, mas funcionou no sentido de manter a desigualdade e a hierarquia ${ }^{41}$.

A partir de uma leitura do Código de 1916, essas observações se confirmam. Tem-se, assim, no art. $6^{\circ}$, II, que as mulheres casadas são relativamente incapazes para alguns atos da vida civil, necessitando da anuência do marido. Beviláqua apresenta suas justificativas:

\footnotetext{
${ }^{40}$ AMARAL, op. cit., 2011. p. 06.

${ }^{41}$ MAIA, Cláudia de Jesus. A invenção da solteirona: Conjugalidade moderna e terror moral: Minas Gerais (18901948). 319f. Tese (Doutorado em História) - Instituto de Ciências Humanas, Universidade de Brasília. Brasília, 2007. Disponível em: < http://migre.me/uxyCS > Acesso em: 01 ago. 2016. p. 94-95.
} 
Não é a inferioridade mental a base da restricção [sic] imposta à capacidade da mulher, na vida conjugal, é a diversidade das funções que os consortes são chamados a exercer (...). Em tudo aquillo [sic] que exigir mais larga e mais intensa manifestação de energia intelectual [sic], moral e physica [sic], o homem será mais apto do que a mulher; mas em tudo aquillo [sic] em que se exigir dedicação, persistência, desenvolvimento emocional delicado, o homem não se pode equiparar à sua companheira. (Grifos na citação original; manteve-se o português arcaico da citação original $)^{42}$

O artigo 219, IV, por sua vez, considera a ausência de virgindade por parte da noiva como motivo para anulação do casamento; e o artigo 233 estabelece que o marido é o chefe da sociedade conjugal, cabendo-lhe decidir ou não sobre a possibilidade da esposa trabalhar fora de casa; dentre muitos outros dispositivos que reforçam a desigualdade de gênero no interior da família. Sobre essas atribuições jurídicas, a historiadora Cláudia Maia comenta:

O primeiro Código Civil brasileiro regulamentou os direitos civis, dentre eles, o casamento e o desquite. Como uma lei, mas, também e principalmente, como uma prática discursiva, ele criou e assegurou os direitos dentro da sociedade conjugal. Dessa forma, embora historicamente as mulheres tenham ocupado lugar de destaque na família, constituindo-se, em muitos casos, em suas mantenedoras, o código civil, baseado na idéia de prestações e contraprestações mútuas, legitimou a divisão sexual entre trabalho produtivo e reprodutivo e tornou as mulheres casadas incapazes e dependentes. Assim, o código não proibia diretamente o trabalho remunerado das mulheres, mas criava um instrumento jurídico de controle da autonomia delas durante o casamento e após o desquite, já que caberia ao marido autorizar ou proibir a esposa a seguir uma carreira profissional. Além disso, o marido era oficialmente o chefe da sociedade conjugal, cabia a ele a representação legal da família, determinar onde iam morar, e, como detentor do 'pátrio poder' e do "poder marital" podia dispor dos bens tanto do casal como da esposa e, em caso de herança, era, freqüentemente, ele quem recebia como "cabeça do casal" ${ }^{3}$.

Observe-se que a manutenção da ideia do homem como cabeça do casal, presente desde as Ordenações Filipinas, mantem-se no Código Civil de 1916. O artigo 251 trará três situações nas quais a chefia da família incumbirá à esposa:

\footnotetext{
$\overline{42}$ MAIA, op. cit., 2007. p. 100.

${ }^{43}$ Ibidem, 2007. p. 95.
} 
quando o marido estiver desaparecido; estiver preso há mais de dois anos e for judicialmente interditado para os atos da vida civil. Tratam-se de casos atípicos, exceções nas quais não há outra maneira a não ser incumbir a mulher desta posição tradicionalmente masculina.

No que se refere ao divórcio, verifica-se que a redação original do Código regulamentava o desquite como forma de dissolução do casamento. Este, regulamentado pelos artigos 315 e seguintes, só poderia ser realizado com base em adultério, tentativa de morte, injúria grave, abandono do lar por dois anos seguidos ou por mútuo consentimento de cônjuges casados pelo mesmo período. É importante ressaltar que o adultério deixa de ser motivo caso o cônjuge traído tenha contribuído para a sua ocorrência, ou caso perdoe o traidor: esse perdão era presumido nos casos em que se sabia da traição, mas ainda se coabitava com o traidor. Merece destaque, ainda, a questão da culpa como condição primordial para a ação de desquite:

A culpa-condição para ajuizamento da ação de separação litigiosa. A culpa que, caso ausente da inicial de ação de separação, poderia gerar uma decisão preliminar, de extinção do processo por carência de ação, usando a linguagem do nosso Código de Processo Civil. Isso quer dizer que, se o cônjuge ajuíza a ação de separação sem acusar o outro de culpado pela separação e sem pedir que o outro seja julgado culpado pela separação, seu processo nem poderia seguir adiante, pois ausente uma condição para separar-se - a culpa do outro, que denominamos culpa conjugal. Nossa legislação familial exigia essa busca da culpa como condição da ação de separação, [...] no Código Civil (1916), artigo $317^{44}$.

Neste sentido, a pensão alimentícia só era devida às mulheres inocentes e pobres, além do que a mulher condenada perderia o direito de utilizar o nome do marido. Além disso, os desquitados não poderiam contrair novo matrimônio com terceiros, dado o entendimento herdado da tradição romana de que o matrimônio seria indissolúvel. A necessidade de se comprovar a culpa para que haja a dissolução do casamento irá perdurar no Código Civil de 2002, já que a lei estabelecia a separação como requisito para o divórcio, e para se obter a separação o artigo 1.572 afirmava ser necessário "propor a ação de separação judicial, imputando ao outro qualquer

\footnotetext{
${ }_{44}^{4}$ PIZETTA, José. É (des)necessário o exame de culpa conjugal nas ações de separação e de divórcio. In: Novos Estudos Jurídicos - Ano VII - $\mathrm{n}^{\mathrm{o}} 15$ - p. 169-180, dezembro/2002. Disponível em: < http://migre.me/uxyfQ>, Acesso em: 01 ago. 2016. p. 176.
} 
ato que importe grave violação dos deveres do casamento e torne insuportável a vida em comum". A situação só se modificará em 2010, com a Emenda Constitucional no 66, que extinguirá o instituto da separação, podendo qualquer dos cônjuges exigir diretamente o divórcio, nem necessidade de separação e, portanto, de culpa.

Diversas mudanças jurídicas no que se refere ao papel da mulher no direito de família começaram a ocorrer a partir da década de $60^{45}$, no Brasil. Tem-se por exemplo a Lei 6.121, de 1962, conhecida como o Estatuto da Mulher Casada:

O primeiro grande marco para romper a hegemonia masculina foi em 1962, quando da edição da Lei 6.121. O chamado Estatuto da Mulher Casada, devolveu a plena capacidade à mulher, que passou à condição de colaboradora na administração da sociedade conjugal. Mesmo tendo sido deixado para a mulher a guarda dos filhos menores, sua posição ainda era subalterna. Foi dispensada a necessidade da autorização marital para o trabalho e instituído o que se chamou de bens reservados, que se constituía do patrimônio adquirido pela esposa com o produto de seu trabalho. Esses bens não respondiam pelas dívidas do marido, ainda que presumivelmente contraídas em benefício da família ${ }^{46}$.

Todavia, é importante atentar para as permanências de certos papéis, não modificados pela legislação:

Continuaram, porém, as desigualdades, dentre elas, a permanência do homem como chefe da família e detentor do pátrio poder, agora "com a colaboração da mulher", e o direito de fixar o domicílio da família (embora fosse permitido à esposa recorrer ao judiciário, caso o domicílio fixado lhe fosse prejudicial). Também continuou sendo obrigatório o uso do patronímico do marido e a permanência de direitos diferenciados que mantinham a hierarquia ${ }^{47}$.

Já em 1977 seria aprovada a Lei 6515/1977, conhecida como Lei do Divórcio, que possibilitaria a dissolução do matrimônio em solo brasileiro:

\footnotetext{
${ }_{45}$ Talvez frutos dos movimentos de contracultura e contestação da supremacia masculina, que emergiam com a segunda onda do movimento feminista: "As pressões feministas, sobretudo a partir dos anos de 1960, tornaram

${ }^{\circ}$ casamento mais igualitário e ele foi perdendo sua força de controle. Nesse sentido, duas leis foram importantes: o Estatuto da Mulher Casada, lei 4.121, aprovado em 1962, e a lei 6.515 de 1977, que instituiu o divórcio" (MAIA, op. cit., 2007. p. 283).

${ }^{46}$ DIAS, Maria Berenice. A mulher no Código Civil. Disponível em: < http://migre.me/uxyu6> Acesso em: 01 ago. 2016.

${ }^{47}$ MAIA, op. cit., 2007. p. 284.
} 
O passo seguinte, e muito significativo, foi a Lei do Divórcio, aprovada em 1977. Para isso foi necessária a alteração da própria Constituição Federal, afastando o quorum de dois terços dos votos para emendar a Constituição. Passou a ser exigida somente maioria simples e não mais maioria qualificada. Só assim foi possível aprovar a Emenda Constitucional $n^{0} 9$ que introduziu a dissolubilidade do vínculo matrimonial. A nova lei, ao invés de regular o divórcio, limitou-se a substituir a palavra "desquite" pela expressão "separação judicial", mantendo as mesmas exigências e limitações à sua concessão. Trouxe, no entanto, alguns avanços em relação à mulher. Tornou facultativa a adoção do patronímico do marido. Em nome da equidade estendeu ao marido o direito de pedir alimentos, que antes só eram assegurados à mulher "honesta e pobre". Outra alteração significativa foi a mudança do regime legal de bens. No silêncio dos nubentes ao invés da comunhão universal, passou a vigorar o regime da comunhão parcial de bens ${ }^{48}$.

As mudanças mais significativas no que se refere ao direito das mulheres no direito de família, porém, só virão em 1988, com a promulgação da Constituição Federal:

Três eixos nortearam uma grande reviravolta nos aspectos jurídicos da família. Ainda que o princípio da igualdade já viesse consagrado desde a Constituição Federal de 1937, além da igualdade de todos perante a lei $\left(\right.$ art. $\left.5^{\mathrm{a}}\right)$, pela primeira vez foi enfatizada a igualdade entre homens e mulheres, em direitos e obrigações (inc. I do art. $5^{\circ}$ ). De forma até repetitiva é afirmado que os direitos e deveres referentes à sociedade conjugal são exercidos igualmente pelo homem e pela mulher ( $\$ 5^{\circ}$ do art. 226). Mas a Constituição foi além. Já no preâmbulo assegura o direito à igualdade e estabelece como objetivo fundamental do Estado promover o bem de todos, sem preconceito de sexo (inc. IV do art. $2^{\circ}$ ). A isonomia também foi imposta entre os filhos, eis proibida quaisquer designações discriminatórias relativas à filiação. Havidos ou não da relação de casamento, ou por adoção, todos têm os mesmos direitos e qualificações ( $\$ 6^{\circ}$ do art. 227). O próprio conceito de família recebeu da Constituição tratamento igualitário. Foi reconhecida como entidade familiar não só a família constituída pelo casamento. Foram albergadas nesse conceito a união estável entre o homem e a mulher e a comunidade formada por qualquer dos pais e seus descendentes (art. 226). Mesmo após a implantação da nova ordem constitucional, estabelecendo a plena igualdade entre homens e mulheres, filhos e entidades 
familiares, injustificadamente o legislador sequer adequou os dispositivos da legislação infraconstitucional não recepcionados pelo novo sistema jurídico. Mesmo tendo se transformado em normas sem qualquer eficácia, eis que apartadas da diretriz da Lei Maior, continuavam no ordenamento jurídico como letra morta $^{49}$.

Dentre os dispositivos ainda presentes no Código Civil de 1916, embora revogados, pois em discordância com a nova ordem constitucional, estava o relativo ao defloramento como motivo de anulação do casamento, e a família constituída por matrimônio como o modelo legítimo. É apenas com o advento do Código Civil de 2002 que estes dispositivos serão extirpados do direito brasileiro, criando, juridicamente, um cenário menos repressivo no que se refere ao papel da mulher na família, conforme será abordado no próximo tópico.

\section{A FAMÍlIA HOJE: A CONSTITUIÇÃO DE 1988 E 0 CÓDIGO CIVIL DE 2002}

O Código Civil de 2002 consolidou importantes avanços no que se refere à mulher dentro do direito civil e do direito de família: a capacidade relativa, a necessidade de autorização para trabalhar fora de casa, e a submissão à figura do marido são alguns dos dilemas superados, e tais disposições existem hoje como lembranças históricas da tradição machista que permeia o Direito.

Especificamente no que se refere ao Direito de Família, ou melhor, das famílias, tem-se por exemplo uma gama de princípios norteadores para a aplicação da norma. Tem-se, por exemplo, a dignidade, a igualdade, a proibição do retrocesso social, dentre outros ${ }^{50}$; mas o princípio da interpretação conforme a Constituição como um dos principais, uma vez que preceitua que o Código Civil deve sempre ser interpretado à luz das normas constitucionais ${ }^{51}$. Neste sentido,

A chamada Constituição Cidadã patrocinou a maior reforma já ocorrida no direito das famílias. Três eixos nortearam uma grande reviravolta. [...] Já no preâmbulo [a Constituição] assegura o direito à igualdade e estabelece como objetivo fundamental do Estado promover o bem de todos, sem preconceito

\footnotetext{
$\overline{{ }^{4}}$ DIAS, op. cit., p. 02.

${ }^{50}$ DIAS, Maria Berenice. Manual de Direito das Famílias. São Paulo: Editora Revista dos Tribunais, 2015. p. 43.

${ }^{51}$ Ibidem, 2015. p. 39.
} 
de sexo (CF $\left.3^{\circ} \mathrm{IV}\right)$. Além da igualdade de todos perante a lei $\left(\mathrm{CF} 5^{\circ}\right.$ ), pela primeira vez é enfatizada a igualdade entre homens e mulheres, em direitos e obrigações (CF $5^{\circ}$ I). De forma até repetitiva, afirma que os direitos e deveres referentes à sociedade conjugal são exercidos igualmente pelo homem e pela mulher (CF $226 \$ 5^{\circ}$ ). Também foi imposta a isonomia entre os filhos, ao ser proibida qualquer designação discriminatória relativa à filiação. Havidos ou não da relação de casamento, ou por adoção, todos têm os mesmos direitos e qualificações (CF $227 \S 6^{\circ}$ ). O próprio conceito de família recebeu tratamento abrangente e igualitário (CF 226). Foi reconhecida como entidade familiar não só a família constituída pelo casamento. Neste conceito estão albergadas tanto a união estável entre o homem e a mulher como a comunidade formada por qualquer dos pais e seus descendentes ${ }^{52}$.

Todavia, tanto o Código Civil quanto a Constituição Federal não estão imunes a críticas, especialmente no que se refere ao tratamento jurídico da mulher no direito e na família. Existe uma série de dispositivos que ainda compartilham, mesmo que de forma sutil, de uma visão estigmatizada da mulher ${ }^{53}$. É o caso, por exemplo, dos artigos 1.600 e 1.602 do Código, segundo os quais, em casos de adultério mesmo a confissão da mulher não afasta a presunção da paternidade; trata-se de uma forma de desprestigiar a palavra da mulher ${ }^{54}$. Outro exemplo seria o artigo 1.736, I, que estabelece que a mulher casada pode recusar agir como tutora, sem que haja equivalente para o homem casado: "Essa prerrogativa traz o ranço do regime de submissão, que condicionava a vontade da mulher à vênia do marido, tanto que o simples fato de ela ser casada a autoriza a declinar do encargo" ${ }^{25}$.

Dois pontos mais complexos merecem ainda ser mencionados. $O$ primeiro trata da impossibilidade jurídica de escolha do regime de bens para maiores de 70 anos, uma vez que o artigo 1.671, II, estabelece compulsoriamente o regime de separação universal, nesses casos. Para Maria Berenice Dias:

Nada justifica a mantença dessa capitis deminutio, que gera presunção de incapacidade, sem atentar para o fato de que vem aumentando a longevidade e a qualidade de vida das pessoas. A regra denota preconceito contra a chamada "melhor idade", o que é vedado pelo Estatuto do Idoso. A limitação,

\footnotetext{
${ }_{52}$ Dias, op. cit., 2015, p. 103.

53 Ibidem, 2015. p. 104-106.

54 Ibidem, 2015. p. 104.

55 Ibidem, 2015. p. 105.
} 
exclusivamente para a escolha do regime de bens, é desarrazoada, não se conseguindo identificar quem a lei pretende preservar. Ora, se visa a proteger o idoso, protege o homem, pois é ele que, com 70 anos de idade, tem muito mais chance de casar do que uma mulher sexagenária. Assim, se a lei protege 0 noivo idoso, desprotege sua "jovem" pretendente ${ }^{56}$.

É importante destacar, porém, que a regra vale para ambos os sexos de forma que há sim uma certa igualdade. Talvez o legislador devesse ter se atentado mais às consequências sociais da norma, uma vez que na prática é mais comum que homens se casem com mulheres mais jovens, do que o contrário. Assim, um tratamento jurídico baseado na equidade, que levasse em consideração essas práticas sociais, poderia ter tratado do assunto de forma mais sensível, posto que nesses casos os viúvos mais jovens, em sua maior parte mulheres, tendem a ficar patrimonialmente desamparados. Ou, de forma ainda mais plausível, o legislador poderia ter previsto que idade avançada não é sinônimo de fraqueza do entender, para utilizar a expressão das Ordenações Filipinas, e respeitado a vontade individual de cada cônjuge.

O segundo refere-se à eleição do modelo heterossexual ou monoparental como entidade familiar, conforme o artigo 226 da Constituição Federal e a exclusão do reconhecimento de entidades familiares poligâmicas, nos termos do artigo 1.727 do Código Civil. No que se refere ao dispositivo constitucional, foi necessária provocação do poder judiciário ${ }^{57}$ para o reconhecimento de famílias homoafetivas, embora as polêmicas sobre o assunto estejam longe do fim ${ }^{58}$.

Já em relação às uniões poliafetivas, não há nenhum dispositivo legal que proteja os indivíduos envolvidos nestes relacionamentos, de forma que a lei não as reconhece como família. A grande crítica feita por Maria Berenice Dias recai sobre os efeitos patrimoniais, já que apenas os indivíduos em união estável ou casamento terão direito a alimentos e à partilha de bens, excluindo-se os outros consortes. Nas palavras da autora:

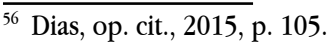

${ }^{57}$ A união estável homoafetiva só foi reconhecida no Brasil após julgamento no Supremo Tribunal Federal. Mais informações: < http://www.stf.jus.br/portal/cms/verNoticiaDetalhe.asp?idConteudo=178931>. Acesso em: 18 jul. 2016.

${ }_{58}$ Tem-se, por exemplo, o Projeto de Lei 6583/2013, mais conhecido como Estatuto da família, que ainda encontra-se em trâmite e no qual apenas uniões heterossexuais ou monoparentais poderiam ser consideradas família. Mais informações em: <http://www.camara.gov.br/proposicoesWeb/fichadetramitacao?idProposicao $=597005>$. Acesso em: 18 jul. 2016 .
} 
Ao se vetar a possibilidade de reconhecimento a essas entidades familiares, se está subtraindo efeitos patrimoniais a um vínculo que - com ou sem o respaldo social ou legal - existe. Mas cabe perguntar: quem mantém uniões simultâneas? Não é um comportamento exclusivamente masculino? Não é o homem que trai? Assim, quem afrontou dogma da monogamia, cometeu adultério e deixou de cumprir o dever de fidelidade? Logo, injustificável que seja beneficiado aquele que mantém um duplo vínculo afetivo. Questiona-se somente a ele a intenção de constituir família. Presume-se que o fato de manter duas entidades familiares significa que não quis formar família com uma ou nenhuma das mulheres. Assim, o homem sai do relacionamento sem qualquer responsabilidade, e o prejuízo é sempre da mulher. $\mathrm{O}$ que parece ser um castigo é um privilégio que só beneficia o parceiro adúltero, que não divide o patrimônio amealhado com a colaboração da mulher nem lhe presta alimentos ${ }^{59}$.

É preciso analisar tal argumento com cuidado, visto que afirmar que a manutenção de relações simultâneas e mesmo de traição são comportamentos exclusivamente masculinos, são falas que beiram o essencialismo. Observe-se que a lei novamente se atém à questão da igualdade jurídica sem observar a realidade social, pois é por questões extrínsecas ao direito que há um privilégio masculino: lhe é ensinado desde cedo que não há problemas e é até aconselhável manter diversas parceiras, de forma que a lei poderia, novamente, ter agido com equidade, levando em consideração essas discrepâncias. Ou, novamente, deixado que adultos maiores e plenamente capazes estabelecessem suas próprias configurações familiares, inclusive com múltiplos consortes.

Desta forma, apesar de importantes conquistas e avanços, o direito de família ainda precisa se atentar a questões importantes, motivo pelo qual é pertinente a afirmação de Maria Berenice Dias: "O Código Civil esqueceu de ver muitas coisas que não são novas. Essas omissões e esses equívocos do legislador fazem com que a sociedade continue a depender da sensibilidade dos juízes. A sorte é que o movimento feminista continua ativo e, ainda que vagarosamente, vem obtendo alguns ganhos" ${ }^{60}$.

\footnotetext{
${ }^{59}$ DIAS, op. cit., 2015. p. 105-106.

${ }^{60}$ DIAS, op. cit., 2015. p. 107.
} 


\section{CONSIDERAÇÕES FINAIS}

O presente ensaio procurou demonstrar de que forma o Direito, especialmente o direito de família, contribuiu e ainda contribui para o tratamento desigual entre homens e mulheres.

Partindo da noção de várias configurações familiares possíveis, foi possível compreender uma virada das sociedades matriarcais às patriarcais, nas quais há uma predominância do masculino sobre o feminino. A Igreja e o Direito serão elementos fundamentais para a manutenção e perpetuação deste sistema, assim como o discurso médico e biológico, que verificava nas mulheres uma condição inferior seja pelo formato do crânio, seja pela menstruação.

Neste sentido, buscou-se resgatar elementos presentes nas legislações brasileiras, desde as Ordenações Filipinas ao Código de 2002, no intuito de verificar e demonstrar como os papéis femininos são tratados diversamente dos masculinos em âmbito familiar.

Como afirmado anteriormente, não se pretendeu analisar os referidos diplomas legais em sua integralidade, mas sim lançar luz a determinados dispositivos que reproduziam (ou reproduzem) certos discursos de desigualdade entre os sexos.

\section{REFERÊNCIAS}

AMARAL, Isabela Guimarães Ribeiro do. Inferiorizando mulheres no período imperial brasileiro: a influência do direito. In: SIMPÓSIO NACIONAL DE HISTÓRIA - ANPUH, 26., 2011. Anais eletrônicos... São Paulo: [s.n.], 2011. Disponível em: < http://migre.me/uxxUf> . Acesso em: 1 ago. 2016.

BECK, Ulrich. Risk Society: Towards a New Modernity. London: Sage Publications, 1992.

BRASIL. Constituição (1824) Constituição Política do Império do Brazil. Rio de Janeiro, 1824. Disponível em: < http://migre.me/uxzzx > . Acesso em: 01 ago. 2016.

BRASIL. Constituição (1891) Constituição da República dos Estados Unidos do Brasil. Rio de Janeiro, 1891. Disponível em: < http://migre.me/uxzAH > . Acesso em: 24 out. 2006. 
BRASIL. Constituição (1988) Constituição da República Federativa do Brasil. 40ª ed. São Paulo: Saraiva, 2007.

BRASIL. Emenda Constitucional no 66, de 13 de julho de 2010. Disponível em: < http://migre.me/uxzNz>. Acesso em: 01 ago. 2016.

BRASIL. Lei no 3.071, de 01 de janeiro de 1916. Código Civil. Disponível em: < http://migre.me/uxzKv>. Acesso em: 01 ago. 2016.

BRASIL. Lei 10.406, de 10 de janeiro de 2002. Código Civil. Disponível em: < http://migre.me/uxzLj > . Acesso em: 01 ago. 2016.

CONSOLIDAÇÃO DAS LEIS CIVIS. Brasília: Senado Federal, 2003.

DIAS, Maria Berenice. A mulher no Código Civil. Disponível em: < http://migre. me/uxyu6>. Acesso em: 01 ago. 2016.

DIAS, Maria Berenice. Manual de Direito das Famílias. São Paulo: Revista dos Tribunais, 2015.

ENGELS, Friedrich. A origem da família, da propriedade privada e do Estado: trabalho relacionado com as investigações de L. H. Morgan. Rio de Janeiro: Civilização Brasileira, 1979.

FONSECA, Ricardo Marcelo. A cultura jurídica brasileira e a questão da codificação civil no século XIX. Revista da Faculdade de Direito da UFPR, v. 44, n. 0, 2006. Disponível em: <http://migre.me/uxzqO>. Acesso em: 01 ago. 2016.

MAIA, Cláudia de Jesus. A invenção da solteirona: conjugalidade moderna e terror moral -Minas Gerais (1890-1948). 2007. 319 f. Tese (Doutorado em História) - Instituto de Ciências Humanas, Universidade de Brasília. Brasília, 2007. Disponível em: < http://migre.me/uxyCS>. Acesso em: 01 ago. 2016.

MURARO, Rose Marie. Breve Introdução Histórica. In: KRAMER, Heinrich; SPRENGER, James. O martelo das feiticeiras. Rio de Janeiro: Rosa dos Tempos, 1997.

ORDENAÇÕES FILIPINAS, livro II. São Paulo: Companhia das Letras, 1999. 
ORDENAÇÕES FILIPINAS, livro IV. São Paulo: Companhia das Letras, 1999.

ORDENAÇÕES FILIPINAS, livro IV. 14. ed. Rio de Janeiro: Typ. do Instituto Philomathico, 1870. Disponível em: < http://migre.me/uxzTS > Acesso em: 01 ago. 2016.

ORDENAÇÕES FILIPINAS, livro V. São Paulo: Companhia das Letras, 1999.

PIMENTEL, Helen Ulhôa. Casamento e sexualidade: a construção das diferenças. Florianópolis: Mulheres, 2012.

PIZETTA, José. É (des)necessário o exame de culpa conjugal nas ações de separação e de divórcio. Novos Estudos Jurídicos, Ano VII, n. 15, p. 169-180, dez. 2002. Disponível em: < http://migre.me/uxyfQ> Acesso em: 01 ago. 2016.

ROSADO, Ruy. Indicação Literária: consolidação das leis civis. In: FREITAS, Augusto Teixeira de. Consolidação das Leis Civis. Brasília: Senado Federal, 2003.

TORRES, Anália Maria Cardoso. Relatório da Unidade Curricular: Sociologia da Família Teorias e Debates. Lisboa, 2010. Disponível em: < http://migre.me/uxx7r>. Acesso em: 01 ago. 2016.

VIEIRA, Flávia David; SILVA, Edvania Gomes da. O instituto do matrimônio nas Ordenações Filipinas: os efeitos de sentido de "casamento" na legislação portuguesa aplicada no Brasil. Linguasagem, São Carlos, v. 23, n. 1, 2015. Disponível em: < http://migre.me/uxxph> Acesso em: 01 ago. 2016.

Recebido em: 02 de agosto de 2016 Aceito em: 12 de janeiro de 2017 